\title{
Thinking of Autonomy as Automatism: the Case of Autonomy in Thucydides' History
}

\section{Pensar la autonomía como automatismo: el caso de la autonomía en la Historia de Tucídides}

\author{
Maria Gerolemou ${ }^{1}$ \\ University of Cyprus (Chipre)
}

Recibido: 15-01-17

Aprobado: 26-02-17

\begin{abstract}
The following article engages in an attempt to review and further explore the notion of autonomy in Thucydides, which is described by scholars as different from freedom, eleutheria, and as primarily assigned to the interests of a weaker state that is trying to exert its independence. Without rejecting the relational aspect of the notion of autonomy, the article argues further on autonomy's internal aspect, ultimately trying to prove how autonomy in Thucydides is moreover presented as an automatic habit and a behavioral pattern that reflects a restrictive, political and artificial perspective of external superior powers.
\end{abstract}

Key-words: Autonomy, Freedom, Automatisms, Automata, Necessity.

\section{Resumen}

Este artículo pretende revisar y explorar la noción de autonomía en Tucídides, considerada por los estudiosos diferente al concepto de libertad, eleutheria, y atribuida esencialmente a los intereses de un estado débil que intenta ejercer su independencia. Sin rechazar el aspecto relacional de

\footnotetext{
1'(gmaria@ucy.ac.cyl) Currently works as an adjunct lecturer at the Classics and Philosophy Department of the University of Cyprus and at the Open University of Cyprus. Her research focuses on ancient drama, primarily through parameters, such as those of gender and madness, on paradoxography and recently on ancient mechanics. She is the author of the book Bad Women, Mad Women: Gender und Wahnsinn in der Griechischen Tragödie (Tübingen, 2011). She is now preparing a volume on the concept of miracle in Antiquity and works on the function of mirrors.
} 
la noción de autonomía, el artículo argumenta sobre su aspecto interno, intentando en último término demostrar que la autonomía en Tucídides es también presentada como un hábito automático y un patrón de conducta que refleja una perspectiva restrictiva, política y artificial de poderes externos superiores.

Palabras-clave: autonomía, libertad, automatismos, autómata, necesidad.

\section{Introduction}

In the following article, I will attempt to review and also to elaborate on the notion of autonomy in Thucydides. Firstly, I will briefly refer to certain important opinions on the matter: According to Bickerman (1958) and Ostwald (1982), autonomia in Thucydides differs from eleutheria, freedom, in being a concept that emerges from interstate relations, mostly describing a weaker state, which is trying to exert its independence. Similarly, Raaflaub (1985) argues that autonomy forms an essential component of Spartan politics and Athenian foreign policy ${ }^{2}$. Moreover, he argues that: "[A]utonomia betont die Selbstbestimmung, eleutheria das Fehlen der Fremdbestimmung [...]" (200). Figueira (1990), on the other hand, argues that autonomy in Thucydides does not always refer the kind of freedom which is granted by a stronger power, and that there is not a sole definition of autonomia that both Athenians and Spartans share. Moreover, the Athenian sense of autonomy is described, according to Figueira, through its indicators, such as the provision of ships (to Athens), the possession of walls and freedom from tributes, whereas, the Spartan idea of independence is formed on the basis of a city's individual and inalienable decision to live under its own laws, beyond any manipulative or distorting external forces and demands, however, in reconciliation with the hegemonic power of Sparta. Based on these grounds and without rejecting the relational aspect of the notion of autonomy, I will argue further on its internal aspect and engage in an attempt to prove that autonomy in Thucydides is, actually, represented as an automatic, un-coerced habit against its restrictive political perspective that relates to external superior powers ${ }^{3}$. Thus, though autonomy in Thucydides does not describe a situation that emerges in the absence of external interferences, at the same time, it appears to be the automatic outcome of an implicit learning process.

\footnotetext{
2015 .

${ }^{2}$ Cf. further on autonomia Bosworth 1992; Whitehead 1993; on freedom see Diller 1968; Nichols

3 This could raise further discussion on the relation between autonomy and the sophistic position physis-nomos; cf. on that Antiph. fr. 44 D-K and Gagarin 2002, 2007.
}

Araucaria. Revista Iberoamericana de Filosofía, Política y Humanidades, año 19, n 37. Primer semestre de 2017. Pp. 199-211. ISSN 1575-6823 e-ISSN 2340-2199 doi: 10.12795/araucaria.2017.i37.10 


\section{Automatic Autonomy}

Without making any reference to Stoic ideas on autonomy as self-imposed and innate -that would be beyond the scope of this paper ${ }^{4}$ - autonomy in Thucydides is defined as an intrinsic property of persons, which can be also tied to norms; in this sense, it differs from free will, which constitutes the basis of freedom. Autonomy is characterized as a human inclination that grounds basic rights, i.e. without serving the pursuance of a specific goal that people can decide whether or not to attain; sometimes it is even defined as the outcome of the interaction between an individual's biology, environment and cognition (as in the below case of Themistocles that this paper explores). By being an innate behavior pattern, autonomy exhibits a certain regularity, and it is in line with automatisms that describe natural unconscious activities, i.e. self-caused action, such as breathing, walking etc., as well as social habits, such as reading, dressing, obeying the laws etc 5 .

In this respect, the classical era approaches autonomy in terms of relatively recent debates, such as the one on automaticity. But let us explore first, though briefly, the ancient notion of automation: The concept of automation forms, according to Hippocratic authors, a constituent part of the forces that operate in the body. In her book The Symptom and the Subject (2010), Holmes argues that the study of human nature and the effects of the visualization of the inner body in Hippocratic writings have revealed its hidden forces; specifically, Hippocratic writers have concluded that the body operates in a spontaneous, regular manner, automata (cf. e.g. Epid. 5.1.19, Art. 46.29), ek tyches, randomly, or, when the physician forcibly intervenes, according to his guidance and knowledge ${ }^{6}$. Thus, medical writers seem to relate both tyche and automaton to a purpose that is, however, reached or missed in an unpredicted and unplanned manner, while, at the same time, they do not consider these as contradictory to motivated actions and techne $e^{7}$. Although the forces in the body are hidden, a trained physician may reconstruct them, based on empirical evidence and methods of inference, and thus manipulate them to favour a certain treatment. In other words, medical treatises suggest the possibility of conscious shaping of bodily automatisms through prescribed by the doctors therapies, such as diets, that facilitate or replace natural process (cf. e.g. Aphorisms).

Aristophanes in his Clouds brings a comic analogon to the possible control of natural automatisms through human techne. He portrays Strepsiades offering both his body and his self to Socrates, the grand teacher, didaskalos,

\footnotetext{
${ }^{4}$ See e.g. Cooper 2003; Id. 2004.

5 See on "automatisms" Bublitz, Marek, Steinmann, Winkler 2010.

${ }^{6}$ See further Schiefsky 2005: 5-13. On the difference between tyche (confined to mature human world) and automaton (confined to nature) see Guthrie 1981, vol. 6 on Aristotle, p. 238-239.

7 Holmes 2010: 142-147; Holmes 2013.
} 
in the phrontisterion, and allowing him to manipulate it as it pleases him, in the hope of learning how to deceive his enemies (439-441). On the other hand, in the Homeric epics, for instance, automation accompanies inanimate corpora constructed by the gods, which provoke wonderment. An exemplary case constitutes the famous scene in the Iliad 18. 372-7 where Thetis visits Hephaestus in his workshop to request a shield for Achilles; the scene captures Hephaestus sweating as he labors for creating twenty triple-legged tables with the ability to imitate movement, in order to automatically roll to the assembly of the gods and back home ${ }^{8}$; what is described here with the term 'automaton' is actually the artificial reproduction, or else the outcome of the divine craft of Hephaestus and of the physical movement which is inserted to the tripods 9 .

Likewise, in Herodotus, natural automation as well as its artificial replication remains subordinate to a divine nous or to the purposively teleological plan of nature. Herodotus, for instance in 2.94.1, describes how in Greece castor-berries, $\sigma \iota \lambda \lambda \iota \kappa v ́ \pi \rho \imath \alpha$, grow wild, $\alpha$ $\tau$ ó $\mu \alpha \tau \alpha$, while in Egypt they are products of cultivation (cf. e.g. 8.138.2, 4.74). Yet, even non natural automation is explained by Herodotus as the outcome of divine will. As such, are the sacred arms, which are found outside the temple of Athena Pronea and which initiate in an automatic way their own motion (8.37), forming in this way a category of non-scientifically explained, i.e. divine phenomena ${ }^{10}$. Herodotus appears generally reluctant to define automation as the outcome of human agency and craft. In 2.48, for instance, he points to the fact that during Dionysus' feast in Egypt, astonishingly great mechanical phalluses, part of the statues of Dionysus, moved automatically. But on the fact that those genitals are so large and on their ability to move there is a sacred explanation, as Herodotus tell us, which of course he never mentions.

The question to be asked next is how the conception of autonomy is defined within the field of automaticity that has just been described. As argued above, autonomy, suggesting an uninformed decision, reveals automatic techniques of self-governing. For example, references on Thracian autonomy in terms of living in a non-organized state exist already in Herodotus (Hdt. 5.3.1). Similarly, in Thucydides, the Thracians are often called autonomous on the basis of living in an open-choice system; for instance, in 2.98.3 many Thracians follow Sitalces, the king of the Thracian Odrysians, and his army without being forced, aparakletoi (see further 2.96.2-4; 2.29.2) ${ }^{11}$. Moreover, in the Hippocratic Corpus the term autonomy is solely used four times, specifically in the De aere aquis et locis, where the ethnic character of Europe and Asia is explained on

\footnotetext{
${ }^{8}$ Cf. further on automatism in Homer e.g. Il. 5.749, 8. 393, Od. 8. 555-563.

9 Generally on automata in antiquity, see among others Pugliara 2003 (with a bibliographical overview on the subject in pp. xxvi-xxxi); Francis 2009: esp. at 8-10.

${ }^{10}$ Cf. Shimron 1989; Thomas 2000: ch. 5.

11 On the special interest of Thucydides in the Thracians see Zahrnt 2006: 610-4.
} 
the basis of an environmental determinism ${ }^{12}$. In 16.17-39, the author tries to elucidate how the unwarlike character of the Asians is influenced by the nature of the seasons, who remain unchangeable to heat or cold; at the same time, however, argues the author further, the Asians seem to avoid the risks of war because of their despotic political system, i.e. because of their non-independent status that does not allow them to benefit from war ${ }^{13}$. Due to these, even when a brave man is born among them, he changes his temper according to the status of their non-autonomy obviously reflecting back to temperamental indifference. In contrast, as the author of the treatise argues, "[a]11 the inhabitants of Asia, whether Greek or non-Greek, who are not ruled by despots, but are independent, toiling for their own advantage, are the most warlike of all men"14 (see e.g. Hdt. 1.95.2, 1.96.1). It is apparent here that both, i.e. autonomy and climatic data, constructed in analogy, are perceived as responsible for creating an essential model on the formation and the development of an ethnic identity.

Likewise, in one of the oldest works where the concept of autonomy is employed ${ }^{15}$, namely Sophocles' Antigone, autonomy emerges as a natural condition against the dominance of social institutions. More explicitly, Sophocles uses the term 'autonomy' to describe Antigone's attitude or character in defying her uncle's rules and the laws of Thebes for the sake of the unwritten laws of the gods ${ }^{16}$. The autonomous way of Antigone is identified with her spontaneous action to set the laws of the gods above the laws of the state and, as a woman, to cherish her deceased relatives ${ }^{17}$; it is actually the way marked by the structuralist reading of the play as the natural way, which derives from Antigone's youth and female nature, that is analogous through opposition to the non-natural way of Creon, due to his male, civic identity ${ }^{18}$. Who could be a

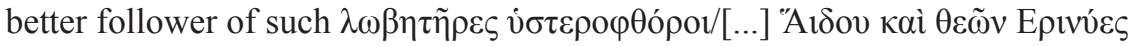
(1074f.), the avenging destroyers, the Furies of Hades and the gods, if not a politically inexperienced girl, still a virgin and without a citizen status? To elaborate, it is precisely because she is non married that she cannot adequately

${ }^{12}$ Cf. Thomas 2000: esp. ch. $3 \& 4$.

${ }^{13}$ Cf. Ostwald 1982: 12; Figueira 1990: 64, n. 5.

${ }_{14}$ Tr. Jones (Loeb).

${ }^{15}$ Ostwald 1982: 10f., Raaflaub 1985: 205; Figueira 1990: 110; Cooper 2004.

${ }^{16}$ See Blundell 1989: 128: “[...] Antigone is a law into herself”; similar Goldhill 1986: 103 and Jebb 1891 ad loc: "of your own free will"; See further Kamerbeek 1978 and also Griffith 2008 ad loc.

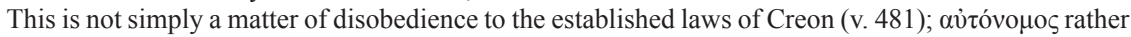
means 'weird' than 'disobedient'. A woman who acts and who stands against the authority of the ruler is strange enough. See further Else 1976: 63-82.

${ }_{17}$ See on that Tyrrell und Bennett 1998: 19, 27. See further siehe Loraux 1992: passim; cf. Alexiou 1974: $15-22$.

${ }^{18}$ Antigone stands closer to nature and away from organized society. For instance, her voice is compared to that of a bird (423-5); she is often apostrophized as an animal (477f, cf. also 433, 775) and in v. 569 as earth $(\Gamma \alpha i \alpha)$. See also the comparison of Antigone with Niobe, the mater dolorosa (826f., and Soph. El. 148-152), who in the end becomes a part of nature, a stone $\pi \varepsilon \tau \rho \alpha i ́ \alpha \beta \lambda \alpha \dot{\sigma} \tau \alpha$, ö $\mu \rho \rho$, 
assess political life and its constituent regulations. However, only she, and not her sister Ismene (also not married), can articulate the 'physical' or family ties against the 'artificiality' of political life and laws, because only she, as Ismene remarks, strikes the impossible amêchanon (92) ${ }^{19}$. She does not, as a woman, merely raise her voice against a man, but rather, as the drama shows in its length, sees and loves death less than life (361f., 220, $\theta \alpha v \varepsilon \tilde{i} v \tilde{\alpha} \rho \tilde{\alpha})^{20}$. The chorus calling her action autonomous (821), indeed expresses the concern with regards to a tradition that is based on the dubious relationship between self-education (autodidakton) and outside instruction (didache), here, from the civic nomoi formed by Creon; this becomes more obvious, when the chorus describes her further as autognotos, self-willed for insisting on her pious action to bury her brother according to the laws of the gods, risking in this way to dishonor the laws of men (875; cf. 1028).

Likewise, the case of Themistocles in Thucydides teaches us important autonomy lessons; his greatness and strength of judgment is effectuated by his natural prudence and his self-imposed genius (autoschedios), which is worthy of admiration ${ }^{21}$. According to Thucydides, "[...] Themistocles was a man who had most convincingly demonstrated the strength of his natural sagacity, and was in the very highest degree worthy of admiration in that respect. For by native in-sight, not reinforced by earlier or later study, he was beyond other men, with the briefest deliberation, both a shrewd judge of the immediate present and wise in forecast" $(1.138 .3)^{22}$. From this perspective, Themistocles can be, for instance, contrasted to Euagoras, as described by Isocrates, who although "gifted by nature with the highest intelligence and capable of successful action in many fields, yet he judged that he should not slight any matter or act on the spur of the moment in public affairs" (9.44; cf. Xen. Mem., 3.5.22, Hell. 5.2.32 $)^{23}$. The autonomy of Themistocles, in terms of his "self-taught" (automathes) and instinctive praxis, is disassociated from pre-determined politics, and this essentially constitutes an analogy to Athenian autonomy, as described by Thucydides with the occurrence of migration from the countryside into the city in 431. More specifically, the Athenians were living, according to Thucydides (2.16.1), autonomously in the countryside despite the synoikism that was delineated by the laws of their country and which was forcing them to migrate into the city (cf. 6.88.4). The same notion of autonomy designed and

${ }^{19}$ On Antigone's anti-confirmative action concerning her gender-identity, see Gerolemou 2011: ch. 5 .

${ }^{20}$ See Benardete 1975: 164, $193 \mathrm{f}$.

${ }^{21}$ On Themistocles in Thucydides see Erbse 1968: 607-615; Tsakmakis 1995: 139-144, esp. 143f.

${ }^{22}$ Tr. Smith (Loeb). One could argue that Themistocles' self-determination is reminiscent of the Stoic terminology that was attached to wise people, whose all actions were determined by nature, as they considered that the proper understanding of how nature works to be of primary importance. Cf. Cicero's Stoic Paradoxes 5, sec. 34 on the autonomy of the wise.

${ }^{23}$ Tr. Hook (Loeb). 
represented as against laws of man pervades Pericles in Funeral Oration (2.3446), where the idea of the Athenian eleutheria, freedom and democracy shares with autonomy the self-determination that should define public life (2.37.2). The citizen's body is autarchic (autarkes) insofar as it is freely to choose if it wishes to obey the laws of the country; it is, then, mere deos, fear that prevents the citizens of Athens from transgressing the laws and not hetero-determined forces that work as a warning of the consequences for breaking the law. Moreover, the Athenians do not rely on preparations but upon their own courage (2.39.1) and, generally, they are not used to laborious exercises (in their youth); this however does not restrict their readiness to confront great dangers. Rather, without labour and based on natural rather than doctrinal braveness ${ }^{24}$, although they believe in being instructed before they act (2.40.2-3), they willingly fight any threat (2.39.4; cf. 6.33.2). On the other hand, Archidamus defends the Spartan way of life, especially in deference to the law that maintained Sparta as a free city for such a long period of time (1.84.1-3). Moreover, Xenophon in his Constitution of the Lacedaemonians 3.1-4, praises Lycurgus' laws, in contrast to the habits which are noted in other cities, where boys are allowed to behave according to their own laws (autonomoi); in Sparta the autonomy of teenage boys is constrained with constant tutoring (cf. Isocrates Panathenaicus 215 6-9).

\section{Constructed Autonomy}

Autonomy as an inherent value is unintentional and not governed by external powers; still as an automatism, i.e. something unconsciously repeatable, it establishes a high degree of order, and it could be conceived as a generative force that gives rise to a concept of autonomy that has constructed features and boundaries. The term appears during the years of the Delian league ${ }^{25}$. The tyrannical activities of Athens towards its allies force the conscious goal of freedom, eleutheria, which is expressed by the allies, to prevail over autonomy that is forced to adapt its unconscious character adjust its unconscious character to a purposive rationality. It is this kind of autonomy-freedom that is conveyed to the allies by the Spartans as an objective, usually in an active tone and in the form of maxims like "saving Hellas", or "freeing Hellas"26; although Sparta

${ }^{24}$ On the other hand, Nicias, in his attempt to inspirit his soldiers (including the many nonAthenians), after their defeat during the Sicilian expedition (7.60-2), argues that if one has knowledge of the Greek language and is able to imitate the Athenian manners, could be considered Athenian and, as such, be honored and admired throughout Hellas (cf. 2.37, 4.62-4, 5.97).

${ }^{25}$ Raaflaub 1985, 191f., 203; see further on the origins of the concept Bickerman 1958 (located in sixth century BC) and Ostwald 1982 (fifth century BC). We cannot trace it beforehand, though see Hdt. 8.140 where the term used by Mardonius is a synonym of freedom.

${ }^{26}$ Cf. Raaflaub 1985, 204-7; Figueira 1990, 64; Tamiolaki 2010, ch. 2. 
does not seek complete independence for the allies but rather the restoration of their original status within the Hellenic league. The Spartans are portrayed as the ones who will give back to Greece its freedom (cf. e.g. 2.8.4, 4.85.1; cf. further 1.124.3, the Corinthians, 1.139.1 the Aeginetans, 2.71.2, 2.72.1 the Plataeans) and effectuate the previous autonomous status of the Greeks (1.139.3, 4.86.1); as defined by Brasidas in 4.86.1, the Spartan state guarantees both a balance of parties and freedom (see also 4.87.5, 4.88.1) ${ }^{27}$. Brasidas argues on the eleutheria from the Athenian tyranny of the citizens of Akanthos, and, simultaneously, on their autonomy in the symmachia ${ }^{28}$. Likewise, in 1.67.2, the Aeginetans assert that, their independence was no longer guaranteed to them kata tas spondas referring to the Thirty Years Peace; their wish is formed on the basis of an argument which sparked the Spartan decision to give an ultimatum to the Athenians with respect to the freedom of the allies ${ }^{29}$. In 5.77.5 and 5.79.1, the concluded treaty between Argos and Sparta (limited to the cities, autopolies) is described as katta patria, i.e. according to a tradition favorable to the interests of Sparta and Argos (cf. 5.18.2) (30 $^{30}$ Moreover, in 1.44.2, Pericles argues that the autonomy of the allies should not be adapted (epitedeios) to the interests of the Spartans ${ }^{31}$, while in 1.140.3-4, the Athenians summarize the claims of the Spartans: "For they command us to arise from before Potidaea and to restore the Aeginetans to the liberty of their own laws and to abrogate the act concerning the Megareans. And they that come last command us to restore all the Grecians to their liberty". For this reason, in 1.144.2, according to Pericles, the Athenians are willing to allow these states to be independent if they held their independence when the peace was concluded (cf. 1.113.4).

On the other hand, the Athenian idea of autonomy appears to be homologous with its natural model explored above, which is formed against legal provisions and conveyed via unconscious procedures that can neither be planned nor predicted. In this respect, the term autonomy is used by the Athenians as a means of claiming from their allies to re-adjust their automatic choice for independence to the new condition, which, ironically, coincides with the establishment of the Athenian $\operatorname{arche}^{32}$ to rule as 'a necessity of nature' (5.105.1-2) ${ }^{33}$. To elaborate, what we have described above as the common automatic and natural aspect of autonomy serves the Athenians by facilitating the conceptualization of an external and, at the same time, artificial autonomy designed according to the Athenian taste; this is legalized through the belief that the Athenian arche is

${ }^{27}$ Cf. Ostwald 1982: 22; Raaflaub 1985: 194.

28 See Bickerman 1958: 326f.

${ }^{29}$ Cf. Ostwald 1982: 23 and Hornblower 1991 ad loc; but see Figueira 1990, 74.

${ }^{30}$ Figueira 1990: 66; See further Bickerman 1958: 333; Ostwald 1982: 3-9; see further Whitehead 1993: 328f.; Hansen 1995: 30.

31 See Figueira (1990) 74.

32 See on the Athenian arche Schuller 1978; Giovannini, Gottlieb 1980.

33 On anagke in Thucydides see Ostwald 1988, esp. ch. 2 and Munson 2001, esp. for Herodotus. 
foremost based on the natural principles that the weaker should obey the one who has more power $(1.76 .2,4.61 .5,5.105 .2)$. This becomes a necessity to which every ally should prioritize over its own needs (cf. Pericles' praise of Athens as a school, paideia for Hellas, 2.41.1). Thereafter, the Athenians are represented as the leaders, irov́revor of the autonomoi symmachoi, of the independent allies (1.97.1). Cleon, for instance in the Mytilenean debate, insists that the Mytileneans were autonomoi enough under their rule (3.39.2). On the other hand, Diodotus, representing the moderate faction in Athens, argues that the eikos, the reasonable, the appropriate always accompanies autonomia; this is what one should have expected, namely that free communities which were subverted by the Athenian hegemony, will someday desire to assert their autonomy (3.45.6). Furthermore, the Mytileneans speaking at the Olympic festivals in front of the allies primarily identify eleutheria with autonomia according to the Spartan idea of autonomy $(3.10 .5 ; 3.11 .1)$. In 3.11.3, however, they describe the type of autonomy which they are enjoying under the Athenian and state by arguing that only in name they are in fact eleutheroi (3.10.5) and their autonomy, here political independence in the symmachia (1.97.1), is constructed solely according to the interests of the Athenians and nourished through euprepeia logou, propriety of speech, gnome, judgement and ischys, power (cf. 3.39.2, 4.86.1) ) $^{34}$. That the desire of freedom should not constitute the basis of autonomy, but rather the imperative of the Athenian arche becomes more obvious in 6.69.3., where there is a differentiation between autonomous allies and non free, upekooi allies fighting together with the Athenians in Sicily. Moreover, in 6.85.2 Euphemus, at the conference at Kamarina, distinguishes between non free, subject allies, autonomous, like Chios and the Methymnians of Lesbos and completely independent allies, eleutheroi, like the islands in the Ionian Sea (but see 7.57.4, 7.57.7 on the restricted autonomy of the Cephallenians, Zacynthians and Chians), which were not members of the symmachia and only had an individual alliance- relationship with Athens ${ }^{35}$. On the other hand, the treaty on the precinct and the temple of Apollo, which guarantees not only its autonomy but also its autoteleia, i.e. to have control of its own revenues and of its own courts of justice, autodikon (5.18.2), approaches the meaning of eleutheria as going against Athens, who wished for Delphi to be under Phokian control $(1.112 .5)^{36}$.

\footnotetext{
${ }^{34}$ Raaflaub 1985: 200

35 See further Raaflaub 1985: 197f. on the autonomy of Aegina, Samos, Lesbos, Chios where he argues on a special status after keeping their former equality relationship to the hegemonic power of Athens.

36 See Hornblower 2008 ad loc, who argues further: "But the present clause may not be wholly one-sided in intention: recent Spartan efforts to maximize their influence in the Delphic amphiktiony, by the foundation in 426 of Herakleia in Trachis [...] have worried the Athenians".
} 


\section{Epilogue}

Based on the principle of human integrity and according to the needs of a certain historical period, autonomy in Thucydides is definitely not a result of human agency, but it is rather an intrinsic situation. As a habit of thought, in Thorstein Veblen's wording, autonomy in Thucydides is being unmasked as reflexive, i.e. automatic, natural. As such, it is formed according to various necessities and external powers and constructs a fait social. More precisely, autonomy, defined as natural inclination, is forced during the Peloponnesian war to take into account people's acquired needs. On the one hand, the Spartan propaganda equates freedom with autonomy, in order for the Spartans to be named as liberator of Greece; on the other hand, the Athenians take advantage of the common natural character of autonomy, which they propagate further in their declarations, with the aim to establish themselves as a natural force. 


\section{Bibliography}

Alexiou 1974: M. Alexiou, The Ritual Lament in Greek Tradition (Cambridge, 1974).

Benardete 1975: S.G. Benardete, A Reading of Sophocles' Antigone, I, "Interpretation", 4 (1975), pp. 148-196.

Bickerman 1958: E. J. Bickerman, Autonomia. Sur un passage de Thucydide (I, 144, 2), "RIDA", 5 (1958), pp. 313-343.

Blundell 1989: M.W. Blundell, Helping Friends and Harming Enemies. A Study in Sophocles and Greek Ethics (Cambridge, 1989).

Bosworth 1992: A.B. Bosworth, Autonomia: the Use and Abuse of Political Terminology, "SIFC", 10 (1992), pp. 122-152.

Bublitz, Marek, Steinmann, Winkler 2010: H. Bublitz, R. Marek, Ch.L.

Steinmann, H. Winkler, coord.: Automatismen (München, 2010).

Cooper 2003: J.M. Cooper, Stoic Autonomy, "Social Philosophy and Policy", 20 (2003), pp. 1-29.

Cooper 2004: J.M. Cooper, The Emotional Life of the Wise, "Southern Journal of Philosophy”, XLIII Supplement (2005), pp. 176-218.

Diller 1968: H. Diller, Freiheit bei Thukydides als Schlagwort und als Wirklichkeit [in Herter 1968], pp. 639-660.

Else 1976: G.F. Else, The Madness of Antigone (Heidelberg 1976).

Erbse 1968: H. Erbse, Zur Geschichtsbetrachtung des Thukydides [in Herter 1968], pp. 594-619.

Figueira 1990: Th. Figueira, Autonomoi kata tas spondas (Thucydides 1.67.2), "BICS", 37, (1990), pp. 63-88.

Francis 2009: J.A. Francis, Metal Maidens, Achilles' Shield, and Pandora: the Beginnings of " ekphrasis», "AJPh", 130.1 (2009), pp. 1-23.

Gagarin 2002: M. Gagarin, Antiphon the Athenian: Oratory, Law, and Justice in the Age of the Sophists, (Austin, Tex., 2002).

Gagarin 2007: M. Gagarin, Nomos and Physis in Antiphon [in A.L. Pierris, coord.: Physis and Nomos: Power, Justice and the Agonistical Ideal of Life in High Classicism, Patras, 2007], pp. 355-80.

Gerolemou 2011: M. Gerolemou, Bad Women, Mad Women: Gender und Wahnsinn in der griechischen Tragödie (Tübingen, 2011).

Giovannini, Gottlieb 1980: A. Giovannini, G. Gottlieb, Thukydides und die Anfänge der athenischen Arche (Heidelberg, 1980).

Goldhill 1986: S. Goldhill, Reading Greek tragedy (Cambridge, 1986).

Griffith 2008: M. Griffith, Sophocles: Antigone (Cambridge, 2008).

Guthrie 1981: W.K.C. Guthrie, A History of Greek philosophy, VI: Aristotle, an Encounter (Cambridge, 1981). 
Hansen 1995: M.H. Hansen, The 'Autonomous City-State'. Ancient Fact or Modern Fiction? [in M.H. Hansen, K. Raaflaub, coord.: Studies in the Ancient Greek Polis, Stuttgart, 1995].

Herter 1968: H. Herter, ed.: Thukydides (WdF 98) (Darmstadt, 1968).

Holmes 2010: B. Holmes, The Symptom and the Subject: the Emergence of the Physical Body in Ancient Greece (Princeton, N.J., 2010).

Holmes 2013: B. Holmes, Causality, Agency, and the Limits of Medicine, "Apeiron", 46 (2013), pp. 302-326.

Hornblower 1991: S. Hornblower, A Commentary on Thucydides, I: Books I-III (Oxford, 1991).

Hornblower 2008: S. Hornblower, A Commentary on Thucydides, III: Books 5.25-8.109 (Oxford, New York, 2008).

Jebb 1891: R. Jebb, Sophocles. The Antigone of Sophocles, edited with introduction and notes (Cambridge, 1891).

Kamerbeek 1978: J.C. Kamerbeek, The Plays of Sophocles: Commentaries. The Antigone. III (Leiden, 1978).

Loraux 1992: N. Loraux, Die Trauer der Mütter: weibliche Leidenschaft und die Gesetze der Politik (aus dem Franz. von E. Moldenhauer, mit einer Einf. von K. Trettin, Frankfurt/Main 1992; Paris, 1992).

Munson 2001: R. Vignolo Munson, Avó $\gamma \eta$ in Herodotus, “JHS”, 121 (2001), pp. 30-50.

Nichols 2015: M.P. Nichols, Thucydides and the Pursuit of Freedom (Ithaca, London, 2015).

Ostwald 1982: M. Ostwald, Autonomia. Its Genesis and Early History, (Atlanta, Ga., 1982).

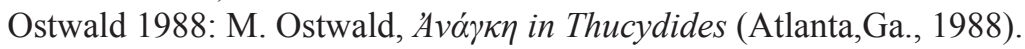

Pugliara 2003: M. Pugliara, Il mirabile e l'artificio: Creature animate e semoventi nel mito e nella tecnica degli antichi (Roma, 2005).

Raaflaub 1985: K.A. Raaflaub, Die Entdeckung der Freiheit. Zur historischen Semantik und Gesellschaftsgeschichte eines politischen Grundbegriffs der Griechen (München, 1985).

Schiefsky 2005: M.J. Schiefsky, Hippocrates on Ancient Medicine, transl. with introd. and commentary (Leiden, 2005).

Schuller 1978: W. Schuller, Die Stadt als Tyrann, Athens Herrschaft über seine Bundesgenossen (Konstanz, 1978).

Segal 1978: Ch. Segal, Sophocles'Antigone; the House and the Cave, "RCCM", 20 (1978), pp. 1171-1188.

Shimron 1989: B. Shimron, Politics and Belief in Herodotus, Stuttgart 1989.

Tamiolaki 2010: M. Tamiolaki, Liberté et Esclavage chez les historiens Grecs classiques, préface de Kurt Raaflaub (Paris, 2010). 
Thomas 2000: R.Thomas, Herodotus in Context: Ethnography, Science, and the Art of Persuasion (Cambridge, New York, 2000).

Tsakmakis 1995: A. Tsakmakis, Thukydides über die Vergangenheit (Tübingen, 1995).

Tyrrell, Bennett 1998: W.B. Tyrrell, L.J. Bennett, Recapturing Sophocles' «Antigone», (Lanham, Md., 1998).

Whitehead 1993: D. Whitehead, Samian Autonomy [in M. Rosen, J. Farrell, coord.: Nomodeiktes, Ann Arbor, 1993], pp. 321-29.

Zahrnt 2006: M. Zahrnt, Macedonia and Thrace in Thucydides [in A. Rengakos, A. Tsakmakis, coord.: Brill's Companion to Thucydides, Leiden, 2006], pp. 589-614. 
